\title{
Extraction-Chromogenic Systems for Vanadium(V) Based on Azo Dyes and Xylometazoline Hydrochloride
}

\author{
Danail G. Hristov, Nikolina P. Milcheva and Kiril B. Gavazov ${ }^{\star}$ \\ Department of Chemical Sciences, Medical University of Plovdiv, 120 Buxton Brothers St., Plovdiv 4004, Bulgaria \\ *Corresponding author: E-mail: kgavazov@abv.bg
}

Received: 05-06-2019

\begin{abstract}
Liquid-liquid extraction-chromogenic systems for vanadium(V) based on xylometazoline hydrochloride (XMZ) and azo derivatives of resorcinol (ADRs) were studied. The following ADRs were used: 4-(2-thiazolylazo)resorcinol (TAR), 5-methyl-4-(2-thiazolylazo)resorcinol (MTAR), and 6-hexyl-4-(2-thiazolylazo)resorcinol (HTAR). Concentration of the reagents, $\mathrm{pH}$ of the aqueous medium and shaking time were subjects of optimization experiments. The chloroform-extracted ternary complexes were of composition 1:1:1. The molar absorptivity coefficients $\left(\varepsilon_{\lambda}\right)$, absorption maxima $(\lambda)$, constants of extraction $(\log K)$, and fractions extracted $(E \%)$ were found to be $\varepsilon_{553}=2.50 \times 10^{4} \mathrm{dm}^{3} \mathrm{~mol}^{-1} \mathrm{~cm}^{-1}, \log K$ $=3.5$, and $E=96 \%(\mathrm{ADR}=\mathrm{TAR}) ; \varepsilon_{550}=1.88 \times 10^{4} \mathrm{dm}^{3} \mathrm{~mol}^{-1} \mathrm{~cm}^{-1}, \log K=3.4$, and $E=98 \%(\mathrm{ADR}=\mathrm{MTAR})$; and $\varepsilon_{554}$ $=2.62 \times 10^{4} \mathrm{dm}^{3} \mathrm{~mol}^{-1} \mathrm{~cm}^{-1}, \log K=5.0$, and $E=99.5 \%$ (ADR = HTAR). The Sandell's sensitivities and Beer's law limits were determined as well.
\end{abstract}

Keywords: 6-Hexyl-4-(2-thiazolylazo)resorcinol; 5-Methyl-4-(2-thiazolylazo)resorcinol; 4-(2-Thiazolylazo)resorcinol; xylometazoline hydrochloride; ion-association; ternary complex

\section{Introduction}

Vanadium, atomic number 23, is the first in the line of essential trace metals $(\mathrm{V}-\mathrm{Zn})$ located in the first transition row of the periodic table. It can exist in a variety of oxidation states (-I, 0, I, II, III, IV, and V), in monomeric, oligomeric and polymeric species, and is the fifth most abundant transition element in the Earth's crust. ${ }^{1}$ Vanadium can enter the environment because of natural processes, such as rock weathering, sediment leaching, volcanic activity, aeolian dust, marine aerosols formation, and wild forest fires. ${ }^{2,3}$ At the levels, provided by these processes, it is considered to be health-promoting, ${ }^{4}$ but it can become toxic in accordance with Paracelsus' principle "the dose makes the poison". Serious health hazards are associated with elevated vanadium concentrations; ${ }^{5-7}$ they are typically related to $V(V)$, the most toxic ${ }^{8,9}$ and one of the most common vanadium's oxidation states in the earth's surface systems. ${ }^{9,10}$

Large amounts of $\mathrm{V}(\mathrm{V})$ have been released in the biosphere because of industrial growth. The main sources of anthropogenic vanadium are the combustion of fossil fuels (especially oil), mining, processing of ores, production of steel alloys, glass, ceramics, rubber, redox batteries and dyes, application in catalysts for large-scale processes, fertilizing and recycling of domestic waste. ${ }^{3,9,11,12}$ At present, vanadi- um has the highest anthropogenic enrichment factor of all trace elements in the atmosphere; it ranks fourth in this factor for global rivers (after antimony, cadmium and nickel). ${ }^{13}$

Many organic reagents have been applied for vanadium preconcentration and determination..$^{810,14-16}$ Among the most promising and widely used are the azo dyes. ${ }^{8,15-24}$ Azo derivatives of resorcinol (ADR), such as 4-(2-pyridylazo)resorcinol (PAR), ${ }^{24,25}$ 4-(2-thiazolylazo)resorcinol (TAR), ${ }^{26,27}$ and 5-methyl-4-(2-thiazolylazo)resorcinol $(\text { MTAR })^{28,29}$ form ternary complexes it the presence of cationic ion-association reagents (CIAR). Their composition, stability, and extraction-chromogenic characteristics depend on the particular pair of reagents. The composition, for example, can be $1: 1: 1,{ }^{26,28} 2: 2: 2,^{29} 1: 2: 3^{25}$ or $1: 2: 1^{30}$ (V:ADR:CIAR). The differences are explained by the possibility of interactions (H-bonding) between ADR and CIAR or between CIAR and the $\mathrm{VO}_{2}$ group, ${ }^{29}$ which is generally stable ${ }^{26,31,32}$ but under certain conditions is prone to lose an oxygen atom. Moreover, $\mathrm{V}(\mathrm{V})$ is stereochemically flexible $;^{33-35}$ the same is true for ADRs which have many conformers $^{36}$ and can be tridentate, bidentate, and even monodentate ligand $s^{37}$ depending on the environment.

Xylometazoline hydrochloride (XMZ) is a substance widely used in the pharmaceutical industry and included in WHO Model List of Essential Medicines. ${ }^{38}$ From a 
Table 1. Reagents in the present study.

4-(2-thiazolylazo)resorcinol (TAR)

chemical point of view, it can be classified as a cationic ion-association reagent. ${ }^{39,40}$ Various extraction-chromogenic systems containing transition metals, XMZ and PAR have been described in the literature. ${ }^{40-44}$ However, to the best of our knowledge, there are no reports involving both $\mathrm{XMZ}$ and thiazolylazo reagents. In the present paper, we discuss three liquid-liquid extraction-chromogenic systems containing $\mathrm{V}(\mathrm{V}), \mathrm{XMZ}$ and thiazolylazo dye TAR, MTAR or 6-hexyl-4-(2-thiazolylazo)resorcinol (HTAR)\}. In contrast to TAR and MTAR, which have been the subject of many experimental and theoretical studies, ${ }^{26,31,36,45}$ HTAR is unexplored reagent. According to the manufacturer, this reagent is part of a collection of rare and unique chemicals. Its formula, along with the formulae of the other reagents, is shown in Table 1.

\section{Experimental}

\section{1. Reagents and Apparatus}

$\mathrm{V}(\mathrm{V})$ solution $\left(2 \times 10^{-4} \mathrm{~mol} \mathrm{dm}^{-3}\right)$ was prepared from $\mathrm{NH}_{4} \mathrm{VO}_{3}$ (puriss. p.a., VEB Laborchemie Apolda, Germany). XMZ and ADRs (TAR, 97\%; MTAR, 95\%; and HTAR) were purchased from Merck. XMZ was dissolved in water; the obtained solutions $\left(2 \times 10^{-2}\right.$ and $2 \times 10^{-4} \mathrm{~mol}$ $\mathrm{dm}^{-3}$ ) were kept in dark-glass vessels. ${ }^{43,44}$ Aqueous solutions of ADRs $\left(2.0 \times 10^{-3} \mathrm{~mol} \mathrm{dm}^{-3}\right)$ were prepared in the presence of $\mathrm{KOH}\left(1-2\right.$ pellets per $\left.100 \mathrm{~cm}^{3}\right) .^{28}$ The acidity of the aqueous phase was set by ammonium acetate buffer (prepared by mixing $2.0 \mathrm{~mol} \mathrm{dm}^{-3}$ solutions of $\mathrm{CH}_{3} \mathrm{COOH}$ and ammonia). The $\mathrm{pH}$ of the buffer solutions was measured using a WTW InoLab 7110 (Germany) instrument with an accuracy of $\pm 0.001 \mathrm{pH}$ units. Absorbance was read using a Ultrospec 3300 pro UV-Vis spectrophotometers (UK), equipped with 1-cm path-length glass cuvettes. Distilled water and additionally distilled commercial chloroform (p. a.) were used throughout the work.

\section{2. General Procedure}

Solutions of $\mathrm{V}(\mathrm{V})$, buffer $(\mathrm{pH} 3.8-6.8)$, ADR and $\mathrm{XMZ}$ were placed into a separatory funnel. The resulting mixture was diluted with water to a total volume of $10 \mathrm{~cm}^{3}$. Then $10 \mathrm{~cm}^{3}$ of chloroform were added and the funnel was shaken for a fixed time interval (up to $10 \mathrm{~min}$ ). After a short wait for phase separation (5-10 seconds), a portion of the chloroform extract was transferred through a filter paper into the cuvette. The absorbance was measured against chloroform or simultaneously prepared blank (containing all the reagents except for vanadium).

\section{3. Determination of the Distribution Ratios and Fractions Extracted}

The distribution ratios $D$ were calculated by the formula $D=A_{1} /\left(A_{3}-A_{1}\right)$, where $A_{1}$ is the absorbance ob-

Table 2. Optimum operating conditions.

\begin{tabular}{|c|c|c|c|c|c|}
\hline $\begin{array}{l}\text { Extraction } \\
\text { system }\end{array}$ & $\underset{\mathbf{n m}}{\lambda_{\text {max }},}$ & $\mathrm{pH}$ & $\begin{array}{c}c_{\mathrm{ADR}} \\
\mathrm{mol} \mathrm{dm}^{-3}\end{array}$ & $\begin{array}{c}c_{\mathrm{XMZ}} \\
\mathrm{mol} \mathrm{dm}^{-3}\end{array}$ & $\begin{array}{l}\text { Extraction } \\
\text { time, min }\end{array}$ \\
\hline V(V) - TAR - XMZ & 553 & 4.7 & $3.0 \times 10^{-4}$ & $6.0 \times 10^{-3}$ & 1.0 \\
\hline $\mathrm{V}(\mathrm{V})$ - MTAR - XMZ & 550 & 4.7 & $4.0 \times 10^{-4}$ & $8.0 \times 10^{-3}$ & 1.5 \\
\hline V(V) - HTAR - XMZ & 554 & 5.1 & $2.0 \times 10^{-4}$ & $4.0 \times 10^{-3}$ & 8.0 \\
\hline
\end{tabular}


tained after a single extraction (under the optimal extraction conditions, Table 2), and $A_{3}$ is the absorbance obtained after a triple extraction under the same conditions. The final volume in both cases (single extraction and triple extraction) was $25 \mathrm{~cm}^{3} .28,29$ The fractions extracted were calculated by the formula $E \%=100 \times D /(D+1)$.

\section{Results and Discussion}

\section{1. Extraction-Spectrophotometric Optimization}

In a slightly acidic aqueous-ethanolic medium $(\mathrm{pH}$ 4.5-5.5), TAR and MTAR react with $\mathrm{V}(\mathrm{V})^{29,46}$ to give red-colored anionic species. In the presence of CIAR, such as tetraphenylarsonium chloride, triphenylmethylarsonium iodide, tetraphenylphosphonium chloride, and tetrazolium salts $27,29,47,48$ and replacing ethanol with a water-immiscible solvent (e. g., chloroform), ternary ion-association complexes are formed. Preliminary investigations on the $\mathrm{V}(\mathrm{V})$ - ADR - XMZ - water - chloroform systems (where ADR = TAR, MTAR or HTAR) confirmed our expectations for hydrophobic, intensely colored and well chloroform-extractable complexes. Spectra of these complexes are shown in Fig. 1. The absorption maxima $\left(\lambda_{\max }\right)$ in chloroform are located at $552-553 \mathrm{~nm}$ (TAR complex), 549-550 nm (MTAR complex) and 553-554 nm (HTAR complex). One can judge that HTAR (spectrum 3) and TAR (spectrum 1) ensure higher molar absorptivity than MTAR (spectrum 2). The blank at $\lambda_{\max }$ is the lowest when ADR = TAR (spectrum 1') and the highest when $\mathrm{ADR}=$ MTAR (spectrum 2'). The latter, however, is significantly lower than the blank for the similar system, ${ }^{28}$

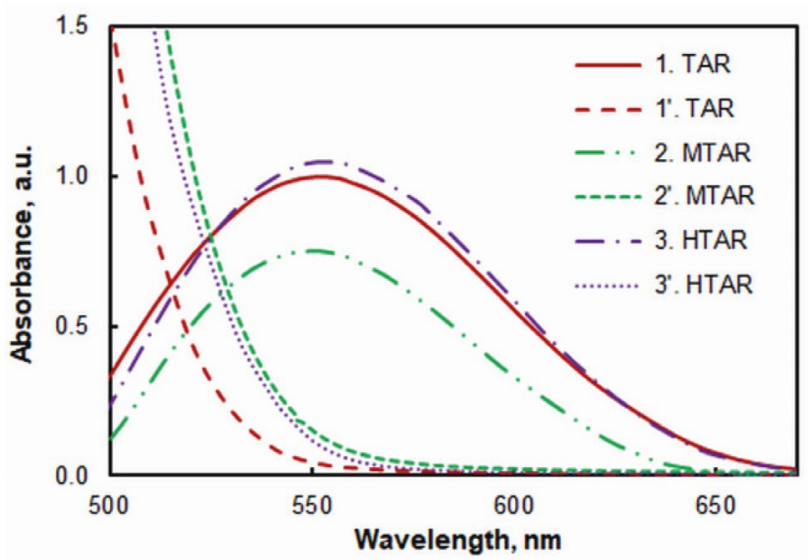

Figure 1. Absorption spectra in chloroform of the $V(V)-A D R-$ XMZ complexes against blanks $\left(1-3 ; c_{\mathrm{V}(\mathrm{V})}=4 \times 10^{-5} \mathrm{~mol} \mathrm{dm}^{-3}\right)$ and blanks (ADR - XMZ) against chloroform $\left(1^{\prime}-3^{\prime}\right) .\left(1,1^{\prime}\right) c_{\mathrm{TAR}}$ $=3 \times 10^{-4} \mathrm{~mol} \mathrm{dm}^{-3}, c_{\mathrm{XMZ}}=6 \times 10^{-3} \mathrm{~mol} \mathrm{dm}^{-3}, \mathrm{pH} 4.7$, extraction time $\mathrm{t}=1 \mathrm{~min} ;\left(2,2^{\prime}\right) c_{\mathrm{MTAR}}=4 \times 10^{-4} \mathrm{~mol} \mathrm{dm}^{-3}, c_{\mathrm{XMZ}}=8 \times 10^{-3}$ mol dm${ }^{-3}, \mathrm{pH} 4.7$, extraction time $\mathrm{t}=2 \mathrm{~min} ;\left(3,3^{\prime}\right) c_{\mathrm{HTAR}}=2 \times 10^{-4}$ $\mathrm{mol} \mathrm{dm}{ }^{-3}, c_{\mathrm{XMZ}}=4 \times 10^{-3} \mathrm{~mol} \mathrm{dm}{ }^{-3}, \mathrm{pH} 5.1$, extraction time $\mathrm{t}=8$ min; containing Aliquat 336 instead of XMZ and isobutanol instead of chloroform.

The effect of $\mathrm{pH}$ of the aqueous phase on the complex formation and extraction is shown in Fig. 2. The absorbance is maximal over the broadest $\mathrm{pH}$ range (4.1-5.6) for $\mathrm{ADR}=\mathrm{TAR}$ (curve 1 ). The left part of this curve resembles the left part of the curve with MTAR (curve 2). Further experiments with TAR and MTAR were performed at $\mathrm{pH}$ 4.7. The optimal $\mathrm{pH}$ for the system with HTAR appears to be 5.1 ; the absorbance in this case abruptly decreases at $\mathrm{pH}>5.6$ (curve 3 ). In all experiments ammonium acetate buffer $\left(1 \mathrm{~cm}^{3}\right)$ was used; it exhibits high buffering capacity at the optimal $\mathrm{pH}$ values. ${ }^{49}$

The effect of ADR and XMZ concentrations on the absorbance is shown in Fig. 3 and Fig. 4 respectively. The selected optimal concentrations are shown in Table 2 . Maximal absorbance is achieved easily (with the lowest re-

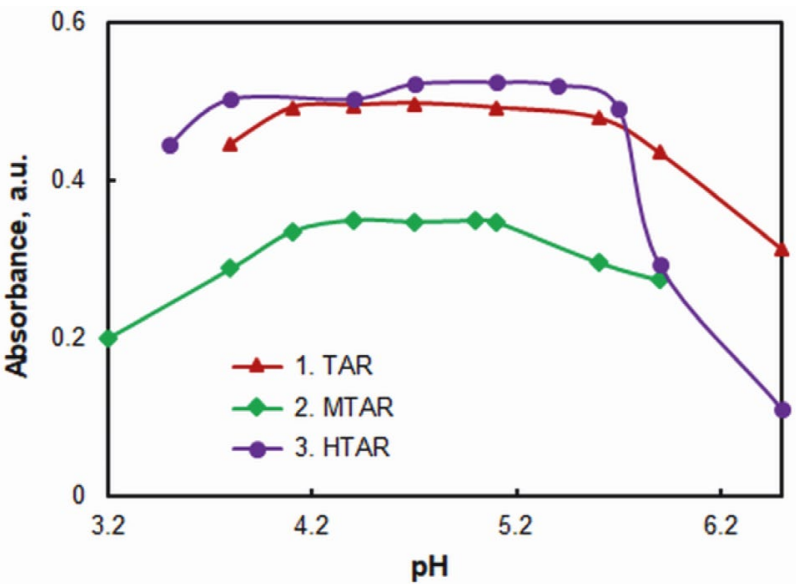

Figure 2. Absorbance of the $\mathrm{V}(\mathrm{V})-\mathrm{ADR}-\mathrm{XMZ}$ complexes $v s \mathrm{pH}$ of the aqueous phase, $c_{\mathrm{V}}=2 \times 10^{-5} \mathrm{~mol} \mathrm{dm}^{-3}$. (1) $c_{\mathrm{TAR}}=3 \times 10^{-4}$ mol dm ${ }^{-3}, c_{\mathrm{XMZ}}=6 \times 10^{-3} \mathrm{~mol} \mathrm{dm}^{-3}$, extraction time $\mathrm{t}=1 \mathrm{~min}$; (2) $c_{\mathrm{MTAR}}=4 \times 10^{-4} \mathrm{~mol} \mathrm{dm}^{-3}, c_{\mathrm{XMZ}}=8 \times 10^{-3} \mathrm{~mol} \mathrm{dm}^{-3}$, extraction time $\mathrm{t}=2 \mathrm{~min}$; (3) $c_{\mathrm{HTAR}}=2 \times 10^{-4} \mathrm{~mol} \mathrm{dm}^{-3}, c_{\mathrm{XMZ}}=4 \times 10^{-3} \mathrm{~mol}$ $\mathrm{dm}^{-3}$, extraction time $\mathrm{t}=8 \mathrm{~min}$;

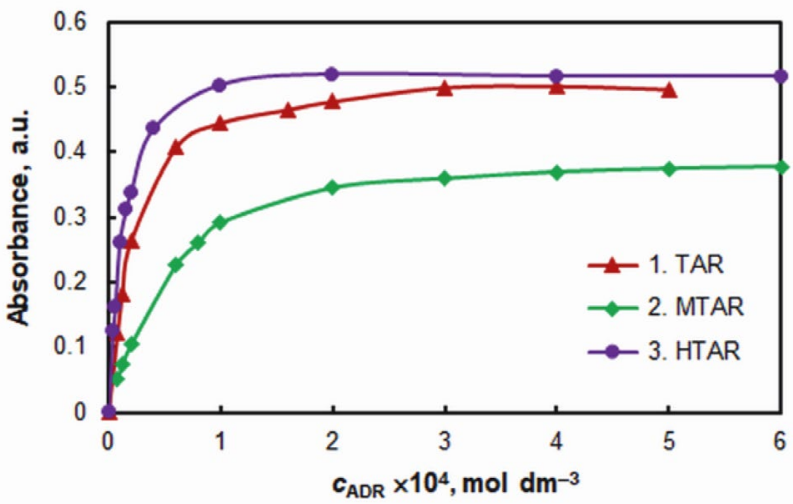

Figure 3. Effect of ADR concentration on the absorbance, $c_{\mathrm{V}}=2 \times$ $10^{-5} \mathrm{~mol} \mathrm{dm}^{-3}$ (1) $c_{\mathrm{XMZ}}=6 \times 10^{-3} \mathrm{~mol} \mathrm{dm}^{-3}, \mathrm{pH} \mathrm{4.7,} \mathrm{extraction}$ time $\mathrm{t}=1 \mathrm{~min} ;$ (2) $c_{\mathrm{XMZ}}=8 \times 10^{-3} \mathrm{~mol} \mathrm{dm}^{-3}, \mathrm{pH} \mathrm{4.7}$, extraction time $\mathrm{t}=2 \mathrm{~min}$; (3) $c_{\mathrm{XMZ}}=4 \times 10^{-3} \mathrm{~mol} \mathrm{dm}^{-3}, \mathrm{pH} 5.1$, extraction time $\mathrm{t}=8 \mathrm{~min}$. 


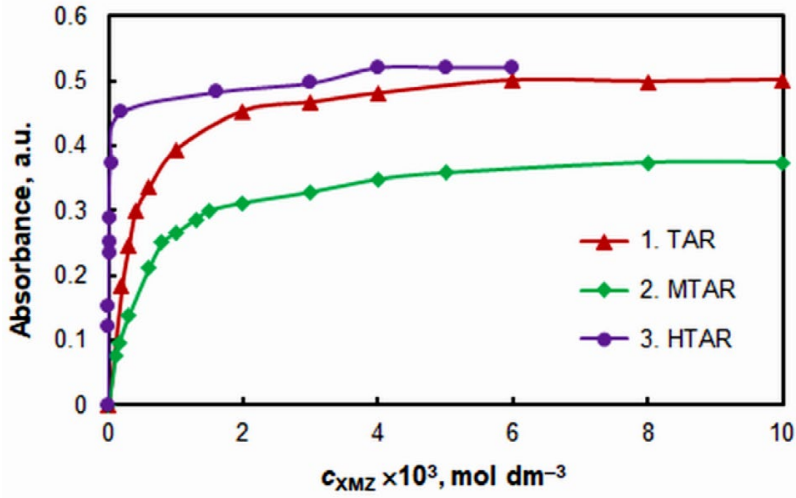

Figure 4. Effect of XMZ concentration on the absorbance, $c_{\mathrm{V}}=2 \times$ $10^{-5} \mathrm{~mol} \mathrm{dm}^{-3}(1) c_{\mathrm{TAR}}=3 \times 10^{-4} \mathrm{~mol} \mathrm{dm}^{-3}, \mathrm{pH} 4.7$, extraction time $\mathrm{t}=1 \mathrm{~min}$; (2) $c_{\mathrm{MTAR}}=4 \times 10^{-4} \mathrm{~mol} \mathrm{dm}^{-3}, \mathrm{pH} 4.7$, extraction time $\mathrm{t}$ $=2 \mathrm{~min}$; (3) $c_{\mathrm{HTAR}}=2 \times 10^{-4} \mathrm{~mol} \mathrm{dm}^{-3}$, pH 5.1, extraction time $\mathrm{t}=$ $8 \mathrm{~min}$.

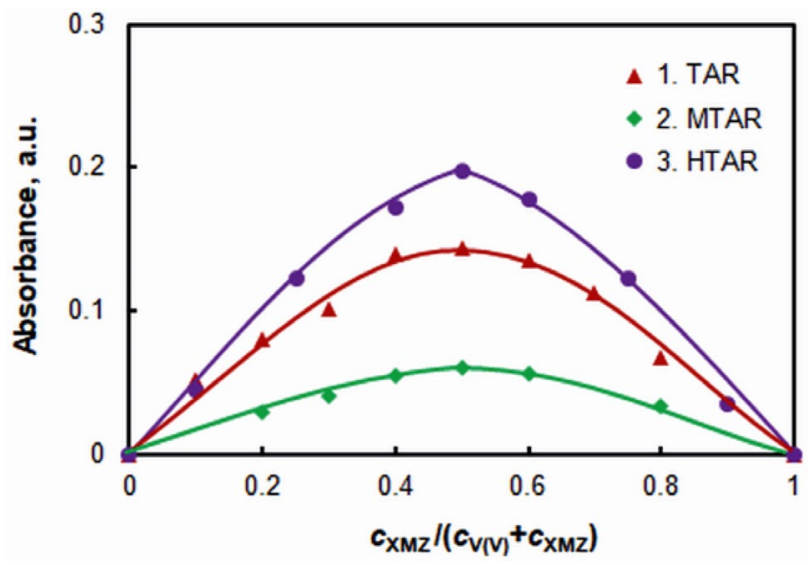

Figure 5. Determination of the XMZ-to-vanadium(V) molar ratio by the Job's method of continuous variations, $c_{\mathrm{XMZ}}+c_{\mathrm{V}(\mathrm{V})}=1.0 \times$ $10^{-4} \mathrm{~mol} \mathrm{dm}^{-3}$. (1) $c_{\mathrm{TAR}}=3 \times 10^{-4} \mathrm{~mol} \mathrm{dm}{ }^{-3}, \mathrm{pH} 4.7$, extraction time $\mathrm{t}=1 \mathrm{~min} ;$ (2) $c_{\mathrm{MTAR}}=4 \times 10^{-4} \mathrm{~mol} \mathrm{dm}^{-3}, \mathrm{pH} 4.7$, extraction time $\mathrm{t}=1.5 \mathrm{~min}$; (3) $c_{\mathrm{HTAR}}=2 \times 10^{-4} \mathrm{~mol} \mathrm{dm}^{-3}, \mathrm{pH} 5.1$, extraction time $\mathrm{t}=8 \mathrm{~min}$.

agents concentrations) for the system with HTAR (curves 3 in Figs. 3 and 4). However, the complex with this reagent is extracted most slowly (Table 2). The time required for shaking in this case ( $8 \mathrm{~min}$ ) is comparable to that recommended when using tetraphenylphosphonium or tetraphenylarsonium chloride (10 $\mathrm{min}) .{ }^{47}$

\section{2. Molar Ratios, Composition and Stability}

The molar ADR-to- $\mathrm{V}(\mathrm{V})$ and $\mathrm{XMZ}$-to- $\mathrm{V}(\mathrm{V})$ ratios were determined by different methods from the experimental results presented in Figs. 3-5. The following methods were used: the mobile equilibrium method, ${ }^{50}$ the straight-line method of Asmus, ${ }^{51}$ the molar ratio meth-

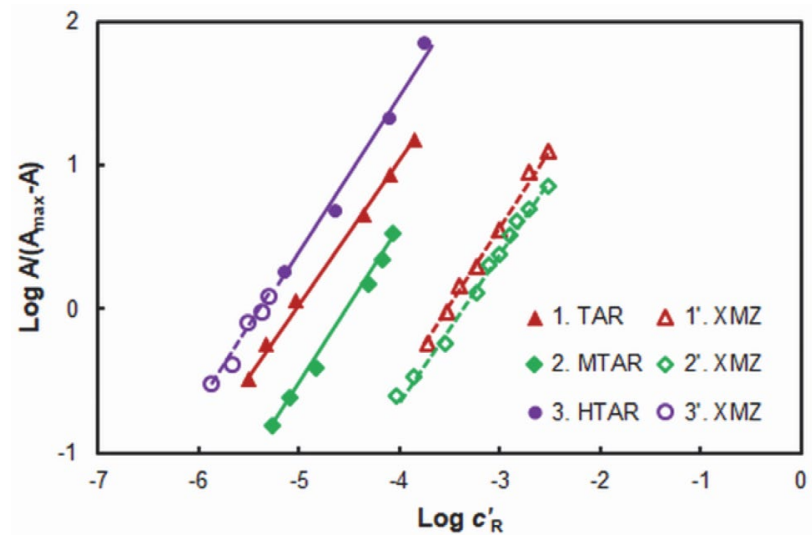

Figure 6. Straight lines obtained by the mobile equilibrium method for ADR-to-V(V) (lines 1-3) and XMZ-to-V(V) (lines 1'-3'). The experimental conditions are given in Fig. 3 and Fig. 4, respectively. Straight lines equations: (1) $\mathrm{y}=0.98 \mathrm{x}+4.95, \mathrm{R}^{2}=0.9984$; (1') $\mathrm{y}=$ $1.13 \mathrm{x}+3.97, \mathrm{R}^{2}=0.9967 ;(2) \mathrm{y}=1.09 \mathrm{x}+4.90, \mathrm{R}^{2}=0.9943 ;\left(2^{\prime}\right) \mathrm{y}=$ $1.01 x+3.42, R^{2}=0.9940 ;(3) y=1.13 x+6.01, R^{2}=0.9840 ;\left(3^{\prime}\right) y=$ $1.07 \mathrm{x}+5.74, \mathrm{R}^{2}=0.9637$.

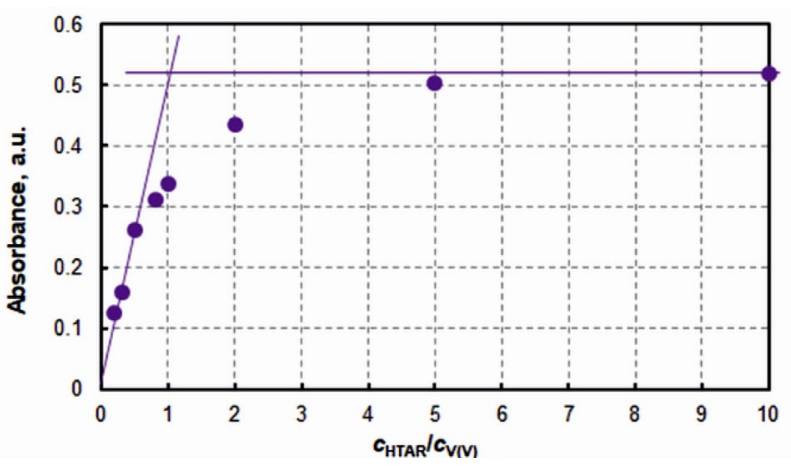

Figure 7. Application of the molar ratio method for the determination of the HTAR-to- $\mathrm{V}(\mathrm{V})$ molar ratio. The experimental conditions are given in Fig. 3, line 3.

Table 3. Molar ratios in the ternary V(V) - TAR - XMZ complexes obtained by different methods

\begin{tabular}{lcccc}
\hline Molar ratio & $\begin{array}{c}\text { Mobile } \\
\text { equilibrium method }\end{array}$ & $\begin{array}{c}\text { Asmus' } \\
\text { method }\end{array}$ & $\begin{array}{c}\text { Job's } \\
\text { method }\end{array}$ & $\begin{array}{c}\text { Molar ratio } \\
\text { method }\end{array}$ \\
\hline TAR : V & $1: 1$ & $1: 1$ & - & Not applicable \\
MTAR : V & $1: 1$ & $1: 1$ & - & Not applicable \\
HTAR : V & $1: 1$ & $1: 1$ & $1: 1$ & Not applicable \\
XMZ : V (V - TAR - XMZ) & $1: 1$ & $1: 1$ & $1: 1$ & Not applicable \\
XMZ : V (V- MTAR- XMZ) & $1: 1$ & $1: 1$ & $1: 1$ & $1: 1$ \\
XMZ : V (V- HTAR - XMZ) & $1: 1$ & $1: 1$ & \\
\hline
\end{tabular}




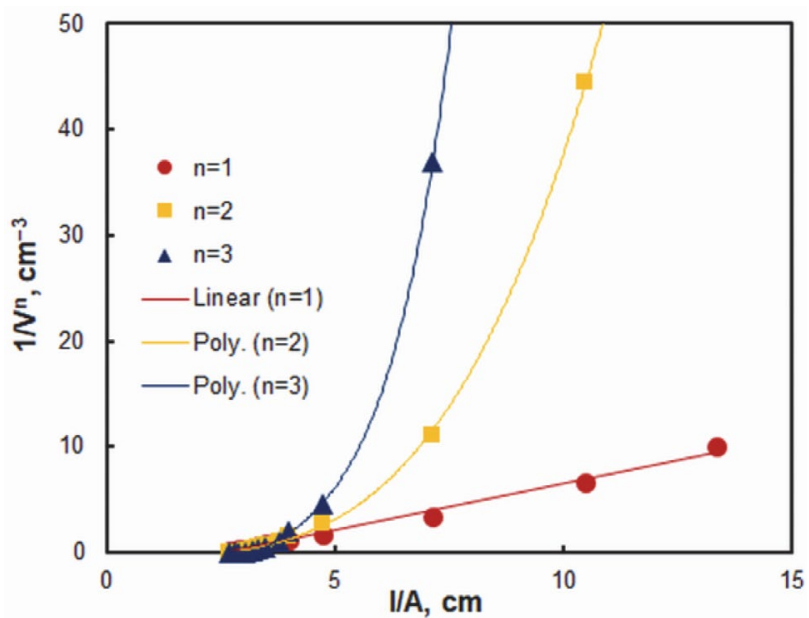

Figure 8. Application of the straight-line method of Asmus for the determination of the XMZ-to- $\mathrm{V}(\mathrm{V})$ molar ratio in the extraction system containing MTAR. The experimental conditions are given in Fig. 4, line 2.

od, ${ }^{52}$ and the Job's method of continuous variations. ${ }^{53}$ As can be concluded from Table 3, and also from Figs. 5-8, all ternary complexes have a composition of 1:1:1. Such a composition was reported for the $\mathrm{V}(\mathrm{V})$ ternary complexes with the couples PAR - XMZ, ${ }^{43}$ TAR - tetraphenylarsonium chloride, ${ }^{47}$ TAR - tetraphenylphosphonium chloride, ${ }^{47}$ and MTAR - Aliquat336. ${ }^{28}$ The complex involving HTAR appears to be the most stable: the molar ratio method can be applied only to it, Table 3 . The isomolar series (Fig. 5) and the straight lines obtained by the mobile equilibrium method (Fig. 6) are also in agreement with this conclusion; curve 3 in Fig. 5 is characterized by a well-defined peak, and curves 3 and 3' in Fig. 6 have the largest $\mathrm{y}$-intercept values.

\subsection{Chemical Equations and Extraction Characteristics}

The formation and extraction of the ternary complexes can be represented in several successive steps. The first step is the formation of binary $\mathrm{V}(\mathrm{V})$ - ADR complexes in aqueous phase (Eq. 1).

$$
\mathrm{VO}_{3}{ }^{-}{ }_{(\mathrm{aq})}+\mathrm{H}_{2} \mathrm{~L}_{(\mathrm{aq})} \rightleftarrows\left[\mathrm{VO}_{2} \mathrm{~L}\right]^{-}{ }_{(\mathrm{aq})}+\mathrm{H}_{2} \mathrm{O}
$$

This equation is based on information concerning the state of $\mathrm{V}(\mathrm{V})^{54,55}$ and ADRs (TAR ${ }^{56}$ and $\mathrm{MTAR}^{57}$ ) at the reaction conditions. Although ADRs can stabilize low oxidation state metal centers, ${ }^{58,59} \mathrm{~V}(\mathrm{~V})$ is not reduced in their presence. This is evidenced by differences in the spectral characteristics and optimal $\mathrm{pH}$ intervals of existence of V(IV)- and V(V)-ARD complexes. ${ }^{37,46,60}$ Furthermore, ADRs have been successfully used for $\mathrm{V}(\mathrm{IV}) / \mathrm{V}(\mathrm{V})$ speciation. ${ }^{8,10,15,61}$ In this case, the main concern is to prevent the oxidation of $\mathrm{V}(\mathrm{IV})$ by the oxygen in air, which starts at $c a$. $\mathrm{pH}>2$ and is rather fast in neutral and alkaline medium. ${ }^{10}$

TAR and MTAR can be considered as triprotic acids. Deprotonated forms of these ADRs are stable in alkaline media $\left(\mathrm{p} K_{1(\mathrm{TAR})}=9.3,{ }^{56,62} \mathrm{p} K_{1(\mathrm{MTAR})}=11.8^{57}\right)$. Monoprotonated forms of TAR and MTAR predominate in neutral and weakly acidic solutions $\left(\mathrm{p} K_{2 \text { (TAR) }}=6.0 ;{ }^{56,62} \mathrm{p} K_{2 \text { (MTAR) }}=\right.$ $\left.5.6^{57}\right)$; the proton is bound to the oxygen atom in ortho-position to the azo group. The neutral forms $\left(\mathrm{H}_{2} \mathrm{~L}\right)$ predominate at lower $\mathrm{pH}$ values. They attach an additional proton (at the nitrogen atom of the thiazole ring) in a highly acidic environment $\left(\mathrm{p} K_{\mathrm{a} 3 \text { (TAR) }}=1.25\right)$. There is no information in the literature about the $\mathrm{p} K_{3}$ (MTAR) nor for the protonation constants of HTAR. However, considering the similar behavior of the blank samples TAR - XMZ, MTAR - XMZ and HTAR - XMZ (Fig. 1), one can assume that these reagents are also in their neutral $\mathrm{H}_{2} \mathrm{~L}$ forms at the optimum $\mathrm{pH}$.

The next steps, ion-association and extraction can be represented simultaneously by Eq. 2 .

$$
\begin{aligned}
& {\left[\mathrm{VO}_{2} \mathrm{~L}\right]^{-}{ }_{(\mathrm{aq})}+\mathrm{XMZ}^{+} \mathrm{Cl}^{-}{ }_{(\mathrm{aq})} \rightleftarrows} \\
& \left(\mathrm{XMZ}^{+}\right)\left[\mathrm{VO}_{2} \mathrm{~L}\right]_{(\mathrm{org})}+\mathrm{Cl}^{-}{ }_{(\mathrm{aq})}
\end{aligned}
$$

In it, $\mathrm{XMZ}$ and its cation are denoted as $\mathrm{XMZ}^{+} \mathrm{Cl}^{-}$ and $\mathrm{XMZ}^{+}$, respectively. The conditional equilibrium constants characterizing Eq. 2 were calculated by two independent methods: the mobile equilibrium method ${ }^{50}$ (Fig. 6, straight lines 1',2' and 3') and the Likussar-Boltz method. ${ }^{63}$ The values obtained by these methods are statistically identical (Table 4). The extraction constant $K$ for the system involving HTAR is the highest. The same is true for the other characteristics listed in Table 4 , the distribution ratio $D$ and

Table 4. Calculated values of the extraction constants $(K)$, distribution ratios $(D)$ and fractions extracted $(E \%)$ at the optimum conditions.

\begin{tabular}{lccc}
\hline Extraction system & $\log K$ & $\log D$ & $E \%$ \\
\hline $\mathrm{V}(\mathrm{V})$ - TAR - XMZ & $3.5 \pm 0.1(\mathrm{~N}=3)^{\mathrm{a}}$ & $1.5 \pm 0.3(\mathrm{~N}=4)$ & $96 \pm 2(\mathrm{~N}=4)$ \\
& $3.52 \pm 0.07(\mathrm{~N}=7)^{\mathrm{b}}$ & & \\
$\mathrm{V}(\mathrm{V})$ - MTAR - XMZ & $3.3 \pm 0.1(\mathrm{~N}=3)^{\mathrm{a}}$ & $1.6 \pm 0.2(\mathrm{~N}=6)$ & $98 \pm 1(\mathrm{~N}=6)$ \\
& $3.39 \pm 0.06(\mathrm{~N}=10)^{\mathrm{b}}$ & & \\
$\mathrm{V}(\mathrm{V})$ - HTAR - XMZ & $5.0 \pm 0.1(\mathrm{~N}=3)^{\mathrm{a}}$ & $2.4 \pm 0.3(\mathrm{~N}=3)$ & $99.5 \pm 0.3(\mathrm{~N}=3)$ \\
& $5.4 \pm 0.5(\mathrm{~N}=5)^{\mathrm{b}}$ & & \\
\hline
\end{tabular}

${ }^{\text {a }}$ Calculated by the Likussar-Boltz method ${ }^{\mathrm{b}}$ Calculated by the molar equilibrium method (Fig. 6) 
Table 5. Characteristics concerning the application of the ternary complexes for extraction-spectrophotometric determination of vanadium(V).

\begin{tabular}{lccc}
\hline Analytical characteristics & V(V) - TAR - XMZ & V(V) - MTAR - XMZ & V(V) - HTAR - XMZ \\
\hline Molar absorptivity $(\varepsilon), \mathrm{dm}^{3} \mathrm{~mol}^{-1} \mathrm{~cm}^{-1}$ & $2.50 \times 10^{4}$ & $1.88 \times 10^{4}$ & $2.62 \times 10^{4}$ \\
Sandell's sensitivity, $\mathrm{ng} \mathrm{cm}^{-2}$ & 2.0 & 2.8 & 2.0 \\
Adherence to Beer's law, $\mu \mathrm{g} \mathrm{cm} \mathrm{cm}^{-3}$ & $0.03-3.6$ & $0.3-3.1$ & $0.07-5.1$ \\
Linear regression equation $\mathrm{y}=a \mathrm{x}+b$ & $\mathrm{y}=0.486 \mathrm{x}+0.001$ & $\mathrm{y}=0.370 \mathrm{x}-0.006$ & $\mathrm{y}=0.513 \mathrm{x}-0.013$ \\
& $\left(\mathrm{R}^{2}=0.9997 ; \mathrm{N}=8\right)$ & $\left(\mathrm{R}^{2}=0.9992 ; \mathrm{N}=8\right)$ & $\left(\mathrm{R}^{2}=0.9991 ; \mathrm{N}=8\right)$ \\
Standard deviations of the slope $(a)$ & $0.004 ; 0.007$ & $0.004 ; 0.007$ & $0.006 ; 0.017$ \\
and y-intercept $(b)$ & & & 0.10 \\
Limit of detection (LOD), $\mu \mathrm{g} \mathrm{cm}-3$ & 0.007 & 0.30 & 0.019 \\
Limit of quantitation (LOQ), $\mu \mathrm{g} \mathrm{cm} \mathrm{cm}^{-3}$ & 0.021 & 0.011 & 0.058 \\
Standard deviation of the blank & 0.001 & 0.003 \\
\hline
\end{tabular}

fraction extracted $E \%$. This is related to the highest hydrophobicity and molecular mass (Table 1) of this reagent.

\section{3. Beer's Law and Analytical Characteristics}

The dependences between the concentration of $\mathrm{V}(\mathrm{V})$ in aqueous phase and absorbance of the extracted ternary complexes were studied under the optimum conditions (Table 2). The linear regression equations and some attendant parameters are listed in Table 5: molar absorptivities, Sandell's sensitivities, Beer's law limits and standard deviation of the slopes, $y$-intercepts and blanks. The limits of detection (LODs) and quantitation (LOQs) were calculated as 3.3- and 10-times standard deviation of the blank divided by the slope. ${ }^{64}$

\section{Conclusions}

Ternary well chloroform-extractable complexes are formed in systems containing vanadium(V), thiazolylazo derivatives of resorcinol (TAR, MTAR, HTAR), and xylometazoline hydrochloride. They have a composition of $1: 1: 1$ and can be represented by the general formula $\left(\mathrm{XMZ}^{+}\right)\left[\mathrm{VO}_{2}(\mathrm{ADR})\right]$, where ADR is in its doubly deprotonated form $\left(\mathrm{ADR}^{2-}\right)$. The complexes have good extraction-spectrophotometric characteristics. The most extractable $(E=99.5 \%)$ and intensively colored $(\varepsilon=2.62 \times$ $\left.10^{4} \mathrm{dm}^{3} \mathrm{~mol}^{-1} \mathrm{~cm}^{-1}\right)$ is the complex of HTAR. The TAR complex is also advantageous. It is formed in the widest $\mathrm{pH}$ range, and the absorbance of the blank at $\lambda_{\max }$ for this reagent is the lowest and repeatable. The latter, along with its high molar absorptivity (95\% of that for the HTAR complex), provides the lowest LOD and LOQ values. Another advantage of the extraction system containing TAR is the shortest time of extraction.

\section{Acknowledgements}

This study is part of a project (DPDP-24) within the framework of a scientific competition "Doctoral and postdoctoral projects-2019" at the Medical University-Plovdiv.

\section{References}

1. A. S. Tracey, G. R. Willsky, E. S. Takeuchi, Vanadium: chemistry, biochemistry, pharmacology and practical applications, CRC press, Boca Raton, 2007, pp. 1-2.

DOI:10.1201/9781420046144

2. W.H.Schlesinger, E. M. Klein, A. Vengosh, Proc. Natl. Acad. Sci. 2017, 114, E1109-E11100. DOI:10.1073/pnas.1715500114

3. B. Gummow, in: Nriagu, J. O., (Ed.): Encyclopedia of Environmental Health, Elsevier, Burlington, 2011; pp. 628-636. DOI:10.1016/B978-0-444-52272-6.00661-9

4. K. Marczewski, B. Marczewska, R. Kuzioła, J. Jpn. Soc. Balneol. Climatol. Phys. Med. 2015, 78, 201-208.

DOI: $10.11390 /$ onki.78.201.

5. D. Rehder, ChemTexts 2018, 4, 20. DOI:10.1007/s40828-018-0074-z

6. K. Gruzewska, A. Michno, T. Pawelczyk, H. Bielarczyk, J. Physiol. Pharmacol. 2014, 65, 603-611.

7. M. R. Awual, M. M. Hasan, A. M. Asiri, M. M. Rahman, J. Mol. Liq. 2019, 283, 704-712. DOI:10.1016/j.molliq.2019.03.119

8. M. J. C. Taylor, J. F. Staden, Analyst 1994, 119, 1263-1276. DOI:10.1039/an9941901263

9. M. Imtiaz, M. S. Rizwan, S. Xiong, H. Li, M. Ashraf, S. M. Shahzad, M. Shahzad, M. Rizwan, S. Tu, Environ. Int. 2015, 80, 79-88. DOI:10.1016/j.envint.2015.03.018

10. K. Pyrzyńska, T. Wierzbicki, Talanta 2004, 64, 823-829. DOI:10.1016/j.talanta.2004.05.007

11. P. N. Linnik, R. P. Linnik, Russ. J. Gen. Chem. 2018, 88, 29973007. DOI:10.1134/S1070363218130273

12. H.-I. Kim, G. Moon, I. Choi, J.-Y. Lee, R. K. Jyothi, J. Clean. Prod. 2018, 187, 449-458. DOI:10.1016/j.jclepro.2018.03.247

13. J. A. Watt, I. T. Burke, R. A. Edwards, H. M. Malcolm, W. M. Mayes, J. P. Olszewska, G. Pan, M. C. Graham, K. V. Heal, N. L. Rose, S. D. Turner, B. M. Spears, Environ. Sci. Technol. 2018, 52, 11973-11974. DOI:10.1021/acs.est.8b05560

14. Z. Marczenko, M. Balcerzak, Separation, preconcentration and spectrophotometry in inorganic analysis, Elsevier, Amsterdam, 2000, pp. 456-465. DOI:10.1016/S0926-4345(00)80119-4 
15. K. Pyrzyńska, Microchim. Acta 2005, 149, 159-164. DOI:10.1007/s00604-004-0304-5

16. W.-y. He, K.-p. Wang, J.-y. Yang, Toxicol. Environ. Chem. 2018, 1-20. DOI: 10.1080/02772248.2018.1428325.

17. T. Stefanova-Bahchevanska, N. Milcheva, S. Zaruba, V. Andruch, V. Delchev, K. Simitchiev, K. Gavazov, J. Mol. Liq. 2017, 248, 135-142. DOI:10.1016/j.molliq.2017.10.046

18. L. Rostampour, M. A. Taher, Talanta 2008, 75, 1279-1283. DOI:10.1016/j.talanta.2008.01.045

19. S. Chandramouleeswaran, J. Ramkumar, Der Chemica Sinica 2018, 9, 605-608.

20. C. Zhang, J. Liu, B. Yao, L. Zhang, in: 2011 International Symposium on Water Resource and Environmental Protection (ISWREP), Xi'an, China, IEEE, 2011, pp. 1803-1806. DOI: 10.1109/ISWREP.2011.5893600.

21. A. S. Amin, A. L. Saber, T. Y. Mohammed, Spectrochim. Acta, Part A 2009, 73, 195-200. DOI:10.1016/j.saa.2009.02.010

22. H. Filik, Z. Yanaz, R. Apak, Anal. Chim. Acta 2008, 620, $27-$ 33. DOI:10.1016/j.aca.2008.05.024

23. H. Filik, K. I. Berker, N. Balkis, R. Apak, Anal. Chim. Acta 2004, 518, 173-179. DOI:10.1016/j.aca.2004.05.012

24. M. Uslu, H. Ulutürk, A. Yartaşı, S. Döker, Toxicol. Environ. Chem. 2014, 95, 1638-1649.

DOI:10.1080/02772248.2014.896920

25. T. S. Stefanova, K. K. Simitchiev, K. B. Gavazov, Chem. Pap. 2015, 69, 495-503. DOI:10.1515/chempap-2015-0048

26. N. Galesic, M. Siroki, Acta Crystallogr., Sect. C 1984, 40, 378381. DOI: $10.1107 /$ S0108270184004212.

27. K. B. Gavazov, V. D. Lekova, A. N. Dimitrov, G. I. Patronov, Cent. Eur. J. Chem. 2007, 5, 257-270. DOI:10.2478/s11532-006-0053-x

28. G. K. Toncheva, N. P. Milcheva, K. B. Gavazov, Acta Chim. Slov. 2018, 65, 847-852. DOI:10.17344/acsi.2018.4491

29. K. B. Gavazov, V. B. Delchev, K. T. Mileva, T. S. Stefanova, G. K. Toncheva, Acta Chim. Slov. 2016, 63, 392-398.

DOI:10.17344/acsi.2016.2431.

30. L. M. Dimova, E. A. Morgen, Zavod. Lab. 1984, 50, 7-9.

31. M. Široki, L. Marić, Z. Štefanac, J. Inorg. Nucl. Chem. 1981, 43, 1151-1153. DOI:10.1016/0022-1902(81)80008-5

32. H. E. Michibata, Vanadium: biochemical and molecular biological approaches. Springer, Dordrecht, 2012.

DOI:10.1007/978-94-007-0913-3

33. S. Kodama, Y. Ueta, J. Yoshida, A. Nomoto, S. Yano, M. Ueshima, A. Ogawa, Dalton Trans. 2009, 9708-9711. DOI:10.1039/b913823d

34. D. C. Crans, J. J. Smee, E. Gaidamauskas, L. Yang, Chem. Rev. 2004, 104, 849-902. DOI:10.1021/cr020607t

35. G. K. Toncheva, Z. T. Zhelev, V. B. Delchev, K. B. Gavazov, Acta Chim. Slov. 2018, 65, 462-469.

DOI:10.17344/acsi.2018.4225

36. Y. Erdogdu, Ü. C. Başköse, S. Sağlam, Chem. Pap. 2019. DOI: $10.1007 / \mathrm{s} 11696-019-00739-4$.

37. K. B. Gavazov, V. B. Delchev, N. P. Milcheva, G. K. Toncheva, Open Chem. 2019 (in press).

DOI: $10.1515 /$ chem-2019-0071.

38. WHO Model List of Essential Medicines, 20th eddition https://www.who.int/medicines/publications/essentialmedicines/en/ (assessed: May 3, 2019)

39. S. Khalil, Microchim. Acta 1999, 130, 181-184.

DOI:10.1007/BF01244925

40. Y. Anjaneyulu, K. Chandra Sekhar, M. Ravi Prakasa Reddy, R. N. Sarma, Microchim. Acta 1985, 87, 23-29.

DOI:10.1007/BF01201983

41. S. N. Bhadani, M. Tewari, A. Agrawal, C. Sekhar, J. Indian Chem. Soc. 1998, 75, 176-177.

42. Y. Anjaneyulu, M. R. Reddy, C. S. Kavipurapu, Analyst 1986, 111, 1167-1169. DOI:10.1039/an9861101167

43. A. Yerramilli, C. S. Kavipurapu, R. R. Manda, C. M. Pillutla, Anal. Chem. 1986, 58, 1451-1453.

DOI:10.1021/ac00298a040

44. C. S. Kavipurapu, S. C. Srivastava, K. K. Gupta, L. P. Pandey, Mikrochim. Acta 1993, 111, 127-132.

DOI:10.1007/BF01240175

45. M. Smolinska, O. Korkuna, T. Vrublevska, P. Rudchuk, G. Teslyar, Open Chem. 2015, 13, 1254-1268.

DOI:10.1515/chem-2015-0139

46. M. Langova, I. Klabenesova, K. Kasiura, L. Sommer, Coll. Czech. Chem. Commun. 1976, 41, 2386-2405.

DOI:10.1135/cccc19762386

47. L. Marić, M. Široki, Z. Štefanac, M. J. Herak, Microchem. J. 1979, 24, 536-544. 3.5, and $\mathrm{E}=96 \%(\mathrm{ADR}=\mathrm{TAR}) ; \varepsilon 550=$ $1.88 \times 104$

48. K. B. Gavazov, T. S. Stefanova, Croat. Chem. Acta 2014, 87, 233-240. DOI:10.5562/cca2436

49. L. Konermann, J. Am. Soc. Mass Spectrom. 2017, 28 , 1827-1835. DOI:10.1007/s13361-017-1739-3

50. Z. Zhiming, M. Dongsten, Y. Cunxiao, J. Rare Earths 1997, $15,216-219$.

51. E. Asmus, Fresenius' J. Anal. Chem. 1960, 178, 104-116. DOI:10.1007/BF00467200

52. J. H. Yoe, A. L. Jones, Ind. Eng. Chem. Anal. Ed. 1944, 16, 111-115. DOI:10.1021/i560126a015

53. P. Job, Ann. Chim. (Paris) 1928, 9, 113-134.

DOI:10.3406/bmsap.1928.9218

54. L. D. Kurbatova, O. V. Koryakova, M. A. Valova, M. Yu. Yanchenko, Z. Anorg. Allg. Chem. 2015, 641, 617-621.

DOI:10.1002/zaac.201400426

55. N. K. Temel, R. Gürkan, Acta Chim. Slov. 2018, 65, 138-149. DOI:10.17344/acsi.2017.3724

56. K. Pytlakowska, V. Kozik, M. Dabioch, Talanta 2013, 110, 202-228. DOI:10.1016/j.talanta.2013.02.037

57. N. Menek, E. Eren, S. Topçu, Dyes Pigm. 2006, 68, 205-210. DOI:10.1016/j.dyepig.2005.01.010.

58. F. Karipcin, E. Kabalcilar, S. Ilican, Y. Caglar, M. Caglar, Spectrochim. Acta - Part A 2009, 73, 174-180.

DOI:10.1016/j.saa.2009.02.012

59. F. Karipcin, E. Kabalcilar, Acta Chim. Slov. 2007, 54, $242-$ 247.

60. N. L. Babenko, A. I. Busev, L. K. Simakova, Zh. Anal. Khim. 1970, 25, 1539-1546.

61. K. B. Gavazov, V. D. Lekova, G. I. Patronov, Acta Chim. Slov. 2006, 53, 506-511. 
62. A. Hulanicki, S. Glab, G. Ackermann, Pure Appl. Chem. 1983, 55, 1137-1230.

DOI:10.1351/pac198355071137
63. W. Likussar, D. F. Boltz, Anal. Chem. 1971, 43, 1265-1272. DOI:10.1021/ac60304a006

64. A. Shrivastava, V. B. Gupta, Chron. Young Sci. 2011, 2, 21-25. DOI:10.4103/2229-5186.79345

\section{Povzetek}

Proučevali smo kromogen sistem ekstrakcije tekočina-tekočina za spojine vanadija (V) na osnovi ksilometazolin hidroklorida (XMZ) in azo derivate resorcinola (ADR). Uporabili smo naslednje ADR: 4- (2-tiazolilazo) resorcinol (TAR), 5-metil-4- (2-tiazolilazo) resorcinol (MTAR) in 6-heksil-4- (2-tiazolilazo) resorcinol (HTAR) . Koncentracija reagentov, $\mathrm{pH}$ vodnega medija in čas stresanja so bili predmet optimizacijskih poskusov. Ternarni kompleksi, ekstrahirani s kloroformom, so bili sestavljeni 1: 1: 1. Določili smo molarne absorbcijske koeficiente $\left(\varepsilon_{\lambda}\right)$, absorpcijske maksimume $(\lambda)$, konstante ekstrakcije (Log K) in delež ekstrahirane frakcije $(E \%): \varepsilon_{553}=2.50 \times 10^{4} \mathrm{dm}^{3} \mathrm{~mol}^{-1} \mathrm{~cm}^{-1}, \log K=\mathrm{dm}^{3} \mathrm{~mol}^{-1} \mathrm{~cm}^{-1}$, $\log K=3.4$, and $E=98 \%(\mathrm{ADR}=\mathrm{MTAR})$; and $\varepsilon_{554}=2.62 \times 10^{4} \mathrm{dm}^{3} \mathrm{~mol}^{-1} \mathrm{~cm}^{-1}, \log K=5.0$, and $E=99.5 \%(\mathrm{ADR}=$ HTAR). Določili smo tudi Sandellovo občutljivosti in omejitve Beerovega zakona. 